\title{
ON WHY ANGER CAN BE POURED, STEELED, AND BOILED: CORPUS-DRIVEN STUDY OF ANGER METAPHORS IN CROATIAN
}

\author{
Jasmina Jelčić Čolakovac* \\ Faculty of Maritime Studies, University of Rijeka
}

The Conceptual Metaphor Theory (CMT) proposed by Lakoff and Johnson (1980) and its exclusion of culture as the motivational mechanism for metaphorical expressions has given rise to other theories such as the Conventional Figurative Language Theory (CFLT) proposed by Dobrovol'skij and Piirainen (2005). The main contribution of this article is the representation of the angerrelated metaphors in the selected corpus of the Croatian language according to their frequency of appearance in non-literal expressions selected via MIP procedure. "ANGER IS HEAT" and its two subversions, "ANGER IS A HOT FLUID IN A CONTAINER" and "ANGER IS FIRE" metaphors, were found to be very productive in Croatian, thus providing further evidence in favor of the universal status of these metaphors. The analysis yielded examples of the "ANGER IS HOT AIR IN A CONTAINER" metaphor as well as the use of different colors to describe anger, thus suggesting that cultural development played a role.

Keywords: anger, conceptual metaphor, universality, corpus study.

\section{INTRODUCTION}

The concept of anger has been discussed to a great extent in literature within the context of cognitive linguistic approaches (Gibbs, 1996, 2003; Kövecses, 2000; Lakoff \& Johnson, 1980; Wierzbicka, 1992). Different languages were analyzed for underlying conceptualizations of anger as an emotional state and it seems that emotions are frequently described in a non-literal, i.e. figurative way. Emotions of happiness and joy, for example, are often tied to the idea of up and above, whereas desperation and sorrow are frequently experienced as something situated down or below. Emotions as such are frequently described in language through metaphorical facets which include, but are not limited to, idioms, metaphors, metonymies etc. These facets represent the notion of figurative language use as opposed to literal language use. When it comes to discerning the meaning of an utterance or a sentence, two factors play a key role in understanding the undergoing processes in the mind of the listener or reader: context and linguistic meaning (Giora, 2002: 489). Based on these factors and the way they interplay in language comprehension, various models 
were proposed in the past with respect to literal and figurative language processing. While some suggest equal processing (at least in the initial phase), other approaches argue against equality and hint at the existence of subtle differences between the ways we understand literal and figurative language. However, to see if differences exist between the literal and figurative language, it is essential to understand the definition of both. Gibbs, Buchalter, Moise, and Farrar (1993: 388-389) make an observation about the lack of a proper definition of literal as opposed to figurative, which has been much discussed in literature. They list the following five meanings of the word literal, which have been most frequently proposed by cognitive linguists:

- conventional literality (in contrast to poetic usage);

- subject-matter literality (the frequency of use for certain expressions);

- non-metaphorical literality (concepts are not understood in relation to other concepts);

- truth-conditional literality (language that accurately depicts existing reality);

- context-free literality (the literal meaning of a word or a phrase is the one existent in context-free conditions).

On the other hand, non-literal, i.e. figurative language, has also undergone many attempts at defining the concept and its practical reach in a given language. Figurative language, it seems, benefits language learners in more ways than one. Wray (2000) explains the beneficial effect of learning to speak figuratively upon memory: "By using figurative language which is in its very definition prefabricated, i.e. formulated, we minimize the effects of our low memory capacities and make for more efficient language users" (Wray, 2000: 15). To further the discussion even more, research has shown that many instances of figurative language use are actually universal in their nature and can be traced back to more than one language. This idea has led scientists into believing there might be something in our cognitive make-ups that forces us to think of concepts in a rather comparative way. The Conceptual Metaphor Theory (CMT) was first introduced by Lakoff and Johnson (1980), who proposed a shift in perspective on metaphor, which is no longer perceived as a decoration of words or simply one of the facets of figurative language in general, but a mechanism in the very core of figurative language processing. They introduced the idea of conceptual metaphors (CMs) as cognitive mechanisms which are common to all language users irrespective of their native languages (L1s). It appears, indeed, that some figurative expressions are governed by metaphors that are universal in nature and shared across different languages, such as time, emotions, and 
self (Kövecses, 2003: 319). To illustrate the notion of universality, Kövecses (2005) can be quoted:

... metaphorical thought is based on bodily experience and neuronal activity in the brain. (...) If metaphor is based on the way the human body and brain function and we as human beings are alike at the level of this functioning, then most of the metaphors people use must also be fairly similar, that is, universal - at least on the conceptual level. (Kövecses, 2005: 34)

The notion of metaphor universality and the role of culture in metaphoric thought, which can be found in the postulates of CMT, has been further explored within the frameworks of other theories, such as the Structural Similarity View (Murphy, 1996), the main meaning focus (Kövecses, 2000), graded salience hypothesis (Giora, 2002), the Conceptual Integration Theory (Fauconnier \& Turner, 2002), Combined Input Hypothesis (Ruiz de Mendoza \& Peña, 2005), and Neural Theory of Metaphor (Lakoff, 2008), to mention but some of the theories put forth in the last decades. Different approaches, understandably, gave rise to different beliefs; from the standpoint that concept similarity and not its metaphoricity is what gives rise to different CMs (Murphy, 1996) to the view that the central knowledge surrounding the source entity in a given speech community is what is being inherited by the target domain (Kövecses, 2000: 82). The latter theory accounts for why many metaphors utilize certain concepts for certain properties, for example in the "ANGER IS HEAT" metaphor, extreme temperature as a feature of heat is mapped because it is one of the main meaning foci associated with heat that derives from the contrast between anger and heat. The graded salience supporters share a similar view of metaphorical language inasmuch as they believe that salient meanings, instead of main ones, are those which take priority in nonliteral language processing (Giora, 2002). On the other hand, theories have been proposed which take into account the role of culture in metaphoric thought, such as the conventional figurative language theory (Dobrovol'skij \& Piirainen, 2005) and dynamical systems theory (Gibbs \& Colston, 2012), which both attempt to incorporate the multiplicity of linguistic and extralinguistic factors in their frameworks.

The aim of this paper is to put the notion of universality to test by conducting a corpus-driven study of target expressions in Croatian in order to construct an extensive representation of anger for the Croatian language. The said representation will then be compared to those which have already been established for other languages, primarily English, in order to delineate any existing differences. Any conclusions drawn from the study carry the potential to be applied to foreign language instruction of figurative language use. 


\subsection{Anger and metaphors}

The general theory of CMs contains at its center the idea of one concept being defined by means of another, i.e., "the essence of metaphor is understanding and experiencing one kind of thing in terms of another" (Lakoff \& Johnson, 1980: 5). This idea can be illustrated by the example of the "ANGER IS HEAT" metaphor in English, which includes the concept of anger to be dealt with in this research. The way English speakers perceive anger is in terms of heat; they can be perceived as instigators of heat themselves when they "breathe fire" or "shoot sparks", or, they experience the increase in bodily temperature as a direct result of their anger whereby their "blood boils" or they "get hot under the collar". Many other expressions have also been found motivated by the said metaphor such as "let someone stew", "let off steam", or "red with anger". All these examples have one thing in common: they perceive anger in terms of heat. Lakoff and Kövecses (1987) proposed a cognitive model of anger in American English, in which CMs played an important role. They also showed that heat metaphors such as the "HOT FLUID IN A CONTAINER" metaphor play a key role in the metaphorical representation of anger in English (Lakoff \& Kövecses, 1987: 159). According to the authors, the most general metaphor for anger, "ANGER IS HEAT", is based on the cultural model of the physiological effects of anger, which include increased body heat and blood pressure, redness in the face, inaccurate perception, etc. The general "ANGER IS HEAT" metaphor is seen as being realized in two different versions, where one refers to solids ("ANGER IS FIRE") and one refers to liquids ("ANGER IS A HOT FLUID IN A CONTAINER"). Lakoff and Kövecses (1987: 197) found the CONTAINER metaphor to be much more elaborated in American English, for which they suggested the following explanation: the existence of the general metaphor "THE BODY IS A CONTAINER FOR THE EMOTIONS". That is to say, the "ANGER IS HEAT" metaphor, in combination to "THE BODY IS A CONTAINER FOR THE EMOTIONS" metaphor, creates the central metaphor in the conceptual system for anger: "ANGER IS THE HEAT OF A FLUID IN A CONTAINER". The cognitive model for anger devised for American English was applied and tested in other languages in the subsequent years, such as Hungarian, Japanese, and Chinese. Many similarities have been found among different languages and their conceptualizations of anger as an emotional state. No comprehensive analyses of anger representation in Croatian exist although some authors have discussed the existence of CMs in Croatian which contain anger as the target domain (Stanojević, 2013). Below are some examples of a non-literal use of the nominal constituent ljutnja 'anger' in Croatian, which have been found in the corpus analysis: 
(1) a. Njegova ljutnja je buknula.

His anger [she] combust-PERF.

His anger combusted.

b. Sipao je ljutnju.

[He] pour-PERF anger.

He poured anger.

c. Razum je ipak nadvladao ljutnju.

Sense still [he] overpower-PERF anger.

Sense still overpowered anger.

These three examples of linguistic evidence suggest that we do think of anger in relation to other concepts and we use the properties of those other concepts to describe the nature of anger. Example (1a) is evidence of the "ANGER IS FIRE" metaphor in Croatian; ljutnja je buknula 'anger combusted' clearly denotes anger in terms of fire properties. Example (1b) perceives anger as a liquid substance (sipao je ljutnju 'he poured anger') and can thus be found as evidence of the "ANGER IS A HOT FLUID IN A CONTAINER" metaphor. Croatian also perceives anger in relation to other concepts, which will further be elaborated in our discussion of the results of our analysis. Example (1c) illustrates one of such concepts and is an example of the "ANGER IS AN OPPONENT" metaphor: nadvladao ljutnju 'it overpowered anger'. We might, thus, define $\mathrm{CMs}$ as a cognitive process of meaning construction on the basis of which we connect the source domain (FIRE or ATTACKER) to the target domain (ANGER) whereby the TARGET DOMAIN IS SOURCE DOMAIN (Lakoff \& Johnson, 1980). In this scenario, our extensive knowledge of source domains helps us grasp the concept of the target domain, which, in our case, is anger.

Not all identified CMs belong to the same category since some CMs are far more elaborate than others and they also might differ in the level at which they are realized. The process of mapping of properties of the source domain onto the target domain is rarely accomplished to the same extent. This is why Lakoff and Johnson (1980: 14) divided metaphors into orientational and ontological, based on how concepts are metaphorically structured in terms of one another. Orientational metaphors would include metaphors such as "HAPPY IS UP", which are more likely to be found across different languages since they stem from basic human experiences. Ontological metaphors, unlike orientational ones, are more specific in nature and are thus prone to cross-cultural deviation in their metaphorical entailments (such would be the "ANGER IS HEAT" metaphor). These orientational metaphors are also sometimes referred to as complex (Boers, 2003; Grady, 1997), whereas orientational metaphors are labelled primary. In this categorization the 
"ANGER IS HEAT" and "ANGER IS FIRE" metaphors would be seen as primary, whereas an example of a complex metaphor would be the "ANGER IS HOT FLUID IN A CONTAINER" metaphor. In Figure 1 there is a visual representation of the subcategorization relationships between metaphorical concepts of fire and heat which support Lakoff and Johnson's (1980: 9) claim stating "metaphorical entailments can characterize a coherent system of metaphorical concepts and a corresponding coherent system of metaphorical expressions for those concepts".

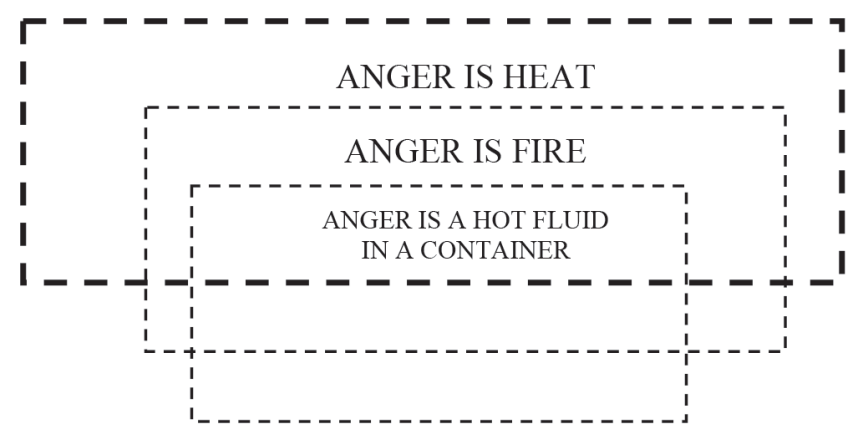

Figure 1. Subcategorization relationships between individual CMs

Regardless of the categorization approach we undertake, there are certain pitfalls to the CMT theory which have been addressed in the past and opposing views have been suggested. For example, Murphy (1996: 179) argues in favor of the structural similarity view according to which there is no "strong form of metaphoric representation - all concepts are directly represented. (...) Instead, the metaphors arise out of the similarity of preexisting conceptual structures (...)." According to this view, the similarity between two concepts is what gives rise to CMs and there is no need to resort to metaphorical concepts as Lakoff and Johnson (1980) did. This view gave rise to some of the main concerns about CMs, around which many arguments have been constructed. Firstly, metaphorical representation does not hold ground according to this perspective, since if it were really a case of a normal relationship between two concepts, those attributes of fire that make less sense in the context of anger would also be mapped between the two domains (Murphy, 1996: 182). The second problematic aspect of the CM view is the existence of different metaphors about the same domain, as we will later report on our findings for the concept of anger in Croatian ("ANGER IS FIRE", "ANGER IS AN OBJECT METAL THAT IS STEELED”, "ANGER IS A LIVING BEING", etc.). Their existence seems to refute the postulate of the CMT view, according to which CMs are causal organizers of the domains and directly influence the way we perceive a certain concept (Murphy, 1996: 185). Although the present study is closely based on CMs, we by no means claim 
$\mathrm{CM}$ is the causal factor behind the mental organization of concepts in our mind. We merely see $\mathrm{CM}$ as a useful tool that might yield a helping hand in vocabulary organization and construction of cognitive models for different concepts. This paper focuses on complex metaphors, since they are more likely to be culture-dependent and thus vary between languages. The reason for this research having concentrated its efforts on complex metaphors is the fact that these CMs are more likely to entail language-specific perceptions of anger, on the basis of which a coherent perception of anger in Croatian could be construed.

\subsubsection{Anger across cultures}

We have already seen that English perceives anger in terms of heat, which is realized in the "ANGER IS HEAT" metaphor. The cognitive model of anger in American English proposed by Lakoff and Kövecses (1987), who offered a physiologically based explanation of anger, was developed even further by Kövecses in his later publications (Kövecses, 1995, 2000). The proposed cognitive model was later tested in other world languages, including Chinese (Chen, 2010; Li, 2010; Yu, 2008) and Japanese (Matsuki, 1995). As for the Chinese language, it was found that Chinese L1 speakers tend to think of anger in terms of air rather than liquid, which is understandable if we take into account that the Eastern doctrine has always been inclined to air (known as Qi) as the source matter for life, whereas the Western tradition has always favored water as the element out of which all life began. This is why there are many examples of the "ANGER IS HOT AIR IN A CONTAINER" metaphor in Chinese, which proved to be more productive than the American English version of the metaphor, "ANGER IS A HOT FLUID IN A CONTAINER" (Li, 2010: 209). Discrepancies with the American English cognitive model of anger have also been recorded in the case of Japanese, where hara 'belly' is perceived as the source, i.e. container for anger which rises when a person gets angry (Matsuki, 1995: 145). Japanese perception of anger was tested against the five-stage scenario for anger proposed by Lakoff and Kövecses (1987): 1) offending event, 2) anger, 3) attempt at control, 4) loss of control, 5) act of retribution. Stage 3 is found to be much more elaborate in Japanese, where anger is controllable, while it is in hara or mune 'chest', which serves as a container for anger overflowing from hara. When a person is ready to lose control over their emotions, that means anger has reached atama 'head' and is ready to burst out (Matsuki, 1995: 146). Kövecses (1995: 186) finds there is clear evidence of the existence of the "ANGER IS A HOT FLUID IN A CONTAINER" metaphor in Japanese, Hungarian, Tahitian, and Wolof, which are only some of the languages where anger is conceptualized through the prism of the container metaphor. 
Other potential factors motivating the emergence of similar expressions in different languages have also been suggested. Dobrovol'skij and Piirainen (2005) have developed an approach to the applicability of CMT in phraseology called the Conventional Figurative Language Theory. As the authors themselves state, what is needed in addition to CMT is a theory "specially designed to describe the irregularities of idioms" (Dobrovol'skij \& Piirainen, 2005: 7). They believe that CMT's disregard for cultural implications of many metaphors is one of its major pitfalls. They propose that the CONTAINER metaphor is not the only motivating factor behind corresponding expressions, but that they are also motivated by an ancient cultural model, where the four fluids (blood, phlegm, black bile, and yellow bile) played the central role (Dobrovol'skij \& Piirainen, 2005: 9-10). This model has persevered in more than one European language and has manifested itself in expressions which are regularly tied to the CONTAINER metaphor instead (e.g., "be yellow-livered" or "someone's gall/bill flows over in English"). Other researchers have agreed with the postulates in this theory and embraced the fact that motivational processes behind many expressions can be understood much more clearly by tracing the etymological roots of the expression (Gevaert, 2005; Omazić, 2014; Sirvydé, 2006). Omazić (2014) lists the example of the English idiom "red herring" ('a distraction that is purposefully designed in order to distract someone'), where the idiom is seen as motivated by metonymic mechanisms, mobilization, and lexicalization, but also by the historical fact of red herrings being used in hunting to distract the hounds with their pungent smell. Omazić (2014: 35) also mentions the example of the idiom "kick the bucket" ('die') in order to illustrate the difficulties with determining motivation behind a certain expression. This idiom has traditionally been classified as opaque in meaning, suggesting its figurative interpretation cannot be implied from the literal meaning of the expression. However, the historical origin of the idiom has already been determined, although three different interpretations exist. The first interpretation goes back to the act of slaughtering hogs, where the animals would be suspended on a wooden frame known as a bucket (Fernando \& Flavell, 1981; Gibbs, 1993; Omazić, 2014). The dead animal would sometimes kick the bucket in an involuntary convulsion of muscles. Fernando and Flavell (1981: 119) suggest two more interpretations: one refers to the suicide tradition mentioned in London Magazine in 1823, when a person hung himself on a beam while standing on a bucket, and the other refers to the tradition upheld by a lynch mob that would stand their victims on a bucket and then the bucket would be knocked from beneath them. Whichever the case, Omazić (2014:35) concludes that expressions such as these, which are motivated by metonymy, are tied to the thought process that motivated them in the first place and are thus more easily interpreted than expressions based on CMs alone. This would 
suggest that even traditionally opaque figurative expressions are motivated; moreover, some of them are perhaps easier to understand than some of the expressions traditionally perceived as more transparent in nature.

\subsection{Metaphor identification}

Another problematic aspect of CMs is their identification in language. Kövecses (2011) argues in favor of the intuitive linguistic methods in metaphor identification, which he deems both useful and necessary since they often yield suggestions that are later corroborated via experimental studies. Intuitive metaphor analysis entails researchers analyzing their own mental lexicons or existing dictionaries in search for examples of certain CMs. Kövecses (2011: 25) also finds intuitive metaphor analysis to be a time-saving method and states "had we waited for a 'rigorous', 'objective', and 'scientific' methodology to reveal all this, we would probably still not have the idea of conceptual metaphor in its entire complexity, pervasiveness, and socialcognitive power." In light of criticism directed towards traditional methods of CM identification, a new approach to the problem has been set forth by The Pragglejaz Group in 2007, who proposed a structured and reliable methodology for metaphor identification called MIP (metaphor identification procedure). The MIP includes four main methodological steps (Pragglejaz Group, 2007):

- reading the text for general understanding of the meaning;

- determining the lexical units in the text;

- establishing the contextual meaning for each lexical unit in the text;

- determining a more basic meaning of a unit (more concrete, related to bodily action, more precise, and/or historically older);

- determining if the contextual meaning contrasts with the established basic current-contemporary meaning but it can be understood in comparison with it;

- if yes, marking the unit as metaphorical.

The four steps outlined above were applied in our corpus search in order to determine contextual and basic meanings for the lexemes analyzed in the study. Such approach to methodology raises the issue of the bottomup and top-down approach to metaphor research. The top-down approach is usually taken by traditional linguists, who draw conclusions based on a small number of examples at which they arrived through intuitive linguistic methods, whereas the bottom-up approach includes large-scale analyses of corpora where figurative language is identified through well-established procedures such as the MIP. While bottom-up research is mainly concerned with extensive analyses of natural discourse, top-down approach focuses 
its efforts on metaphorical structures in thought (Kövecses, 2011: 28). This would suggest that research in which a bottom-up approach was employed is more likely to encounter irregularities in linguistic expression, which cannot be accounted for with higher-level cognitive structures such as CMs. The present study will delineate such irregularities found in the Croatian corpus, however, despite the more extensive, bottom-up nature employed in our research, we do find that linguistic structures can be explained to a great extent by cognitive structures and mechanisms such as CMs (the belief held by supporters of the top-down approach to figurative language analysis). We would, therefore, side with Kövecses (2011), who argued that different meanings of expressions motivated by the same CM can be accounted for within the postulates of CMT. Dobrovol'skij and Piirainen's (2005) argument that expressions "add fuel to the fire" 'to increase the intensity of the argument' and "flare up" 'the intensity of the argument increases suddenly' cannot be motivated by the same CM ("ARGUMENT IS FIRE" in this example), does not hold ground since the "ARGUMENT IS FIRE" metaphor is a more complex metaphor under the "INTENSITY IS HEAT" metaphor (Kövecses, 2002). This is to say that different mappings will apply to the two said expressions: "add fuel to the fire" is motivated by the mapping 'maintaining heat $\rightarrow$ maintaining intensity' and "flare up" is motivated by the mapping 'a sudden increase in the degree of heat $\rightarrow$ a sudden increase in the degree of intensity' (Kövecses, 2011: 32).

\section{ANALYSIS AND DISCUSSION}

A corpus-driven research was initiated in the attempt to construe the representation of anger in the Croatian language. A full-scale search was conducted using the Croatian corpus Hrvatska jezična riznica (Croatian Language Repository) initiated at the Institute of Croatian Language and Linguistics. The corpus aims to be representative of the Croatian standard language by including various functional domains and genres. The Repository consists of literary texts such as novels and poetic pieces, nonfiction, scientific publications such as textbooks, and online journals and newspapers. The study was centered on four Croatian lexemes and their frequency of occurrence within the Repository. The initial corpus search indicated that four synonymous words for anger were most frequently appearing in the corpus in contexts describing anger as an emotional state: ljutnja 'anger', srdžba 'fury', gnjev 'wrath', and bijes 'rage'. All the occurrences containing one of the four targeted lexemes underwent MIP in order to determine whether their use was non-literal in nature. 


\subsection{Descriptive analysis}

The corpus analysis yielded the non-literal, i.e. metaphorical uses for the four targeted lexemes. The frequencies of literal and non-literal occurrences are illustrated in Table 1.

Table 1. Frequencies for the four lexemes $(N=4140)$

\begin{tabular}{c|ccccc}
\hline & $\begin{array}{c}\text { LJUTNJA } \\
\text { 'anger' }\end{array}$ & $\begin{array}{c}\text { SRDŽBA } \\
\text { 'fury' }\end{array}$ & $\begin{array}{c}\text { GNJEV } \\
\text { 'wrath' }\end{array}$ & $\begin{array}{c}\text { BIJES } \\
\text { 'rage' }\end{array}$ & Total \\
\hline Literal use & 523 & 557 & 804 & 1464 & 3348 \\
\hline Non-literal use & 60 & 158 & 234 & 340 & 792 \\
\hline Total & 583 & 715 & 1038 & 1804 & 4140 \\
\hline
\end{tabular}

The corpus search yielded a total of 4140 occurrences, out of which 792 were characterized as metaphorical in nature after the MIP procedure was applied. The non-literal occurrences were subjected to further analysis in order to determine the underlying metaphor, i.e. the motivational mechanism behind the linguistic expression.

The lexeme bijes 'rage' occurred most frequently in the corpus $(f=1804)$ and the highest number of non-literal uses was recorded for the said lexeme accordingly $(f=340)$. On the other hand, the lexeme ljutnja 'anger' recorded the lowest number of frequencies for both literal $(f=523)$ and non-literal uses $(f=60)$. The said lexeme was least frequently used in non-literal context percentage-wise $(10.29 \%)$, whereas the highest percentage of non-literal uses was recorded for gnjev 'wrath' (22.54 \%) (Figure 2).

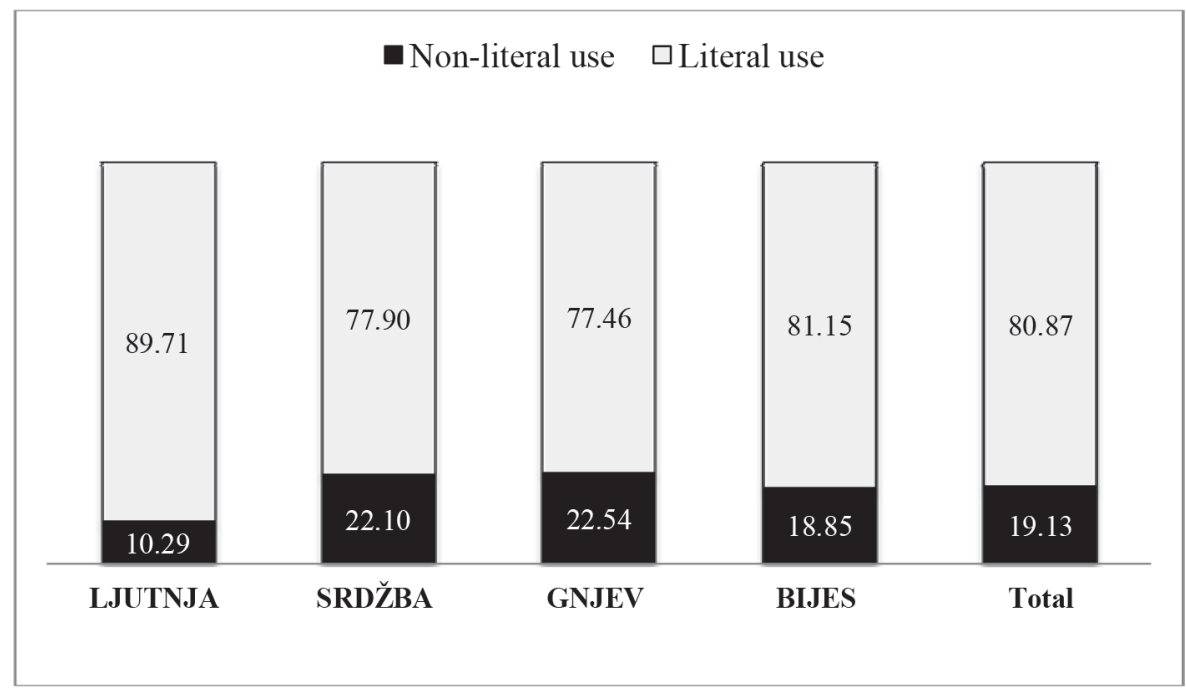

Figure 2. Visual representation of literal and non-literal uses for the four lexemes (\%) 
The non-literal occurrences underwent further analysis, the purpose of which was to categorize the metaphorical uses according to the evident underlying $\mathrm{CM}$. The expressions which were recognized as motivated by one of the anger metaphors low in frequency of occurrence as well as expressions which could not have been categorized under any of the known CMs were labelled as 'unsorted'. The results for all four lexemes can be found in Table 2.

Table 2. Frequencies for the four lexemes according to underlying $C M s(N=792)$

\begin{tabular}{r|ccccc}
\hline & $\begin{array}{c}\text { LJUTNJA } \\
\text { 'anger' }\end{array}$ & $\begin{array}{c}\text { SRDŽBA } \\
\text { 'fury' }\end{array}$ & $\begin{array}{c}\text { GNJEV } \\
\text { 'wrath' }\end{array}$ & $\begin{array}{c}\text { BIJES } \\
\text { 'rage' }\end{array}$ & Total \\
\hline ANGER IS FIRE & 4 & 34 & 62 & 59 & $\mathbf{1 5 9}$ \\
\hline $\begin{array}{r}\text { ANGER IS A } \\
\text { HOT FLUID IN A } \\
\text { CONTAINER }\end{array}$ & 25 & 37 & 77 & 105 & $\mathbf{2 4 4}$ \\
\hline $\begin{array}{r}\text { ANGER IS HOT AIR } \\
\text { IN A CONTAINER }\end{array}$ & 1 & 8 & 6 & 0 & $\mathbf{1 5}$ \\
\hline $\begin{array}{r}\text { ANGER IS AN } \\
\text { OBJECT METAL } \\
\text { THAT IS STEELED }\end{array}$ & 0 & 7 & 17 & 47 & $\mathbf{7 1}$ \\
\hline $\begin{array}{r}\text { ANGER IS A LIVING } \\
\text { BEING }\end{array}$ & 9 & 18 & 19 & 39 & $\mathbf{8 5}$ \\
\hline $\begin{array}{r}\text { ANGER IS AN } \\
\text { OPPONENT }\end{array}$ & 5 & 31 & 28 & 46 & $\mathbf{1 1 0}$ \\
\hline Unsorted & 16 & 23 & 25 & 44 & $\mathbf{1 0 8}$ \\
\hline Total & $\mathbf{6 0}$ & $\mathbf{1 5 8}$ & $\mathbf{2 3 4}$ & 340 & $\mathbf{7 9 2}$ \\
\hline
\end{tabular}

The "ANGER IS A HOT FLUID IN A CONTAINER" motivated the highest number of non-literal occurrences recorded in the corpus $(f=244)$, followed by the "ANGER IS FIRE" $(f=159)$ and "ANGER IS AN OPPONENT" metaphors $(f=110)$. Most of the non-literal occurrences of the lexemes ljutnja, gnjev, srdžba and bijes were motivated by the "ANGER IS A HOT FLUID IN A CONTAINER" metaphor (41.67\%, 32.91\%, 23.42\%, and 30.88\% respectively). The "ANGER IS FIRE" metaphor was the second most frequent motivator for gnjev, srdžba, and bijes lexemes (26.50\%, $21.52 \%$, and $17.35 \%$ respectively). "ANGER IS A LIVING BEING" was the second most frequent motivator for expressions with the lexeme ljutnja (15.00\%). Statistically, the "ANGER IS HOT AIR IN A CONTAINER" was least frequently registered among the occurrences of the four lexemes $(1.89 \%)$. The data for all the metaphors registered in the corpus are presented in Figure 3. 


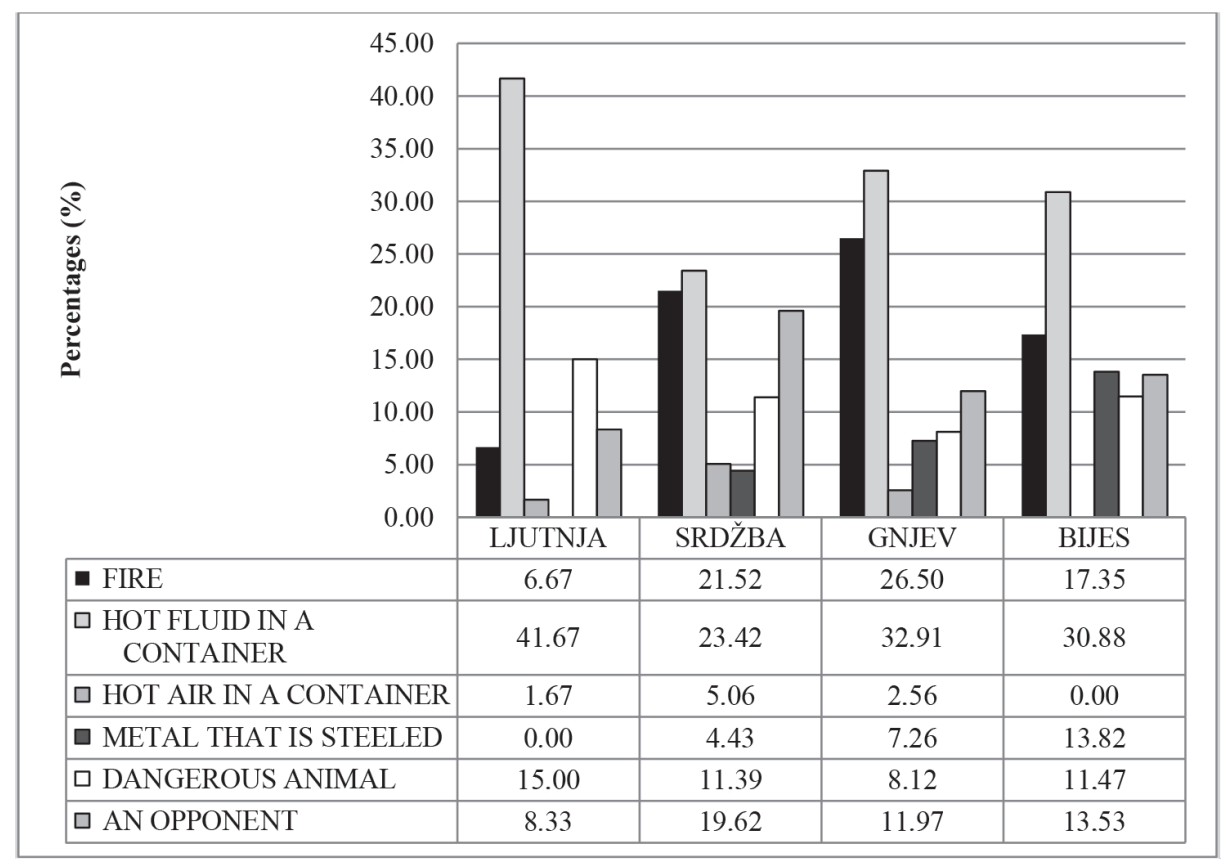

Figure 3. Visual representation of motivating CMs for the four lexemes (\%)

\subsection{The container metaphor}

The non-literal uses were found to be predominantly instantiations of the fluid version of the CONTAINER metaphor, which is most evident in the case of the lexeme ljutnja 'anger', where most of the metaphorical occurrences were motivated by the said metaphor. The examples found in the corpus suggest Croatian L1 speakers think of anger as a liquid by ascribing the physical properties of a liquid to the concept of anger:

(2) a. Gušio se od ljutnje.

[He] suffocate-PERF from anger.

He suffocated in anger.

b. Na njih ću k'o vodu gnjev svoj izliti.

On them [I] like water wrath my spill-FUT.

Upon them I shall spill my wrath like water.

c. Ishlapjeli su moja ljutnja i mržnja.

Evaporate-PERF [they] my anger and hate.

My anger and hate evaporated.

d. Posljedice bojkota razrijedit će ljutnju prema Haideru.

Consequences boycott [they] dilute-FUT anger towards Haider.

Boycott consequences will dilute the anger towards Haider. 
As can be seen in (2a-d), anger is conceptualized as a liquid, whereby anger can also take on some of the physical properties of a liquid, such as evaporation (2c) or dilution (2d). No reference or context is provided regarding the liquid's temperature or pressure, two properties which have been found evident in anger expressions in other languages, such as English and Chinese, where anger is stronger with high temperature and pressure (Chen, 2010). This is not to say that these properties of a liquid are not also registered in Croatian, as can be seen from the following examples:

(3) a. U gazdi je još uvijek kuvao gnjev.

In master [he] more still boil-PERF wrath.

Wrath was still boiling inside the master.

b. Znala mu je uskipjeti krv od gnjeva.

[She] know-PERF him boil-IMPERF blood from wrath.

His blood used to boil from wrath.

c. Iz njega je provalio dugo potiskivani bijes.

From him [he] burst-PERF long pent-up rage.

Long pent-up rage burst out of him.

d. I neka srdžba zakipi u njemu prama Mirku.

And some fury [she] boil-PERF in him towards Mirko.

And fury towards Marko boiled up in him.

e. Bilo je izvjesno da će materina srdžba prekipjeti i razliti se.

[It] be-PERF imminent that [she] mother fury boil-FUT and spillFUT.

It was imminent that the mother's fury would boil up and spill over.

f. Mnogo je ljutnje i gorčine izletjelo iz Christiana Vierija.

A lot anger and bile [it] fly-PERF Christian Vieri.

A lot of anger and bile flew out of Christian Vieri.

g. To je Ankaru odmah dovelo do erupcije ljutnje.

[It] Ankara now lead-PERF to eruption anger.

It immediately drove Ankara into an eruption of anger.

In (3a-g) the liquid's properties pertaining to temperature and pressure are also mapped onto the concept of anger. We can see that anger is like a hot liquid and it behaves as such when exposed to high temperatures (srdžba zakipi 'fury boils up') or internal pressure (bijes je provalio 'rage burst out', erupcija ljutnje 'eruption of anger'). In these cases the body serves as a container for the emotion and if external factors agitate the person, 
temperature and pressure may rise. If they rise too high, the emotion will no longer be contained inside the body and will show externally:

(4) a. Stao se pjeniti od bijesa.

[He] start-PERF foam-IMPERF from rage.

He started foaming out of rage.

b. Pušila se od bijesa.

[She] be-PERF smoke-IMPERF from rage.

She was smoking out of rage.

c. Sad se starom izlije bijes u oči.

Now old man-GEN [it] pour-PERF rage in eyes.

Then rage poured into the old man's eyes.

d. Od gnjeva nam je skočila krv u mlada lica.

From wrath us [she] jump-PERF blood in young faces.

Out of wrath, blood jumped into our young faces.

e. Vratio se brzo nazad, sav crven od gnjeva.

$[\mathrm{He}]$ return-PERF fast, all red from wrath.

He came right back, all red from wrath.

High bodily temperature will demonstrate itself as foaming at the mouth (4a) or smoke coming out of the body (4b). Redness in the facial area is also registered as a sign of anger (4d-e). If we consider the source of anger in the body, our findings suggest heart and the general chest area serves as the container for the emotion unlike the abdomen area in Japanese (Matsuki, 1995):

(5) a. Prekipi mu gnjev, grudi mu usplamte neizmjernim bijesom. Boil-PERF [he] wrath, chest ignite-PERF immeasurable rage. His wrath boiled over, his chest ignited with immeasurable rage.

b. U srcu već mu je kipjelo.

In heart already be-PERF [it] boil-IMPERF.

It was already boiling inside his heart.

c. Mutno je bilo u Mikinoj glavi, a u grudima kuhala srdžba.

Blurry [it] be-PERF in Mika's head, and in chest fury boil-PERF.

It was blurry in Mika's head, and fury boiled in his chest.

Anger starts in the heart (5a), but control is not lost until it reaches the head (5c). It seems that Croatian follows the same scenario for anger as Japanese, in which attempt at control is more elaborate when compared 
to the cognitive model of anger in American English (Lakoff \& Kövecses, 1987). Another version of the CONTAINER metaphor attested in Croatian, the HOT AIR IN A CONTAINER metaphor, proved to be far less elaborate in comparison to Japanese. Nevertheless, there are examples which have been found to suggest 'air' as the central element in the source domain and not 'liquid':

(6) a. U svetom gnjevu naduo bi se kô žaba.

In holy wrath [he] bloat-PERF like toad.

In his holy wrath he would bloat like a toad.

b. Splasnuo je gnjev novovjekovnih inkvizitora.

Deflate-PERF [he] wrath new age inquisitors-GEN.

The wrath of the new age inquisitors deflated.

c. Svi su mu izgledali kao naduti u opravdanom gnjevu.

[They] all seem-PERF to him like bloated-PASS in justified wrath. They all seemed to him bloated in their justified wrath.

d. Nestalo je žalosti, raspršila se srdžba.

[It] go-PERF sorrow, dissipate-PERF fury.

Sorrow went away, fury dissipated.

e. Jedva je disao, koliko ga srdžba nadimala.

[He] barely breathe-PERF, how much fury inflate-PERF.

He could barely breathe from the fury that inflated him.

The lexeme srdžba 'fury' seems to be the most frequent lexeme to appear in the expressions motivated by the HOT AIR IN A CONTAINER metaphor (5.06\%). The Croatian nominal constituent srdžba is derived from the verbal constituent srditi (se) 'become angry' which originates from the Croatian word srce 'heart'. Srdžba 'fury' was semantically constructed from srce 'heart' back in the Proto-Balto-Slavic period, the evidence of which can be found in the existence of similar word forms in other related languages such as Latvian and Lithuanian (Pronk, 2012: 3). Both Baltic and Slavic languages, which originate from the Proto-Balto-Slavic language, exhibit specific linguistic forms not found in any other Indo-European language. It could be that, over the course of their unique historical development, Baltic and Slavic languages came into contact with Asian languages and Eastern cultural models and cross-linguistic borrowing took place. This would suggest that etymological origin does play a role in why certain metaphorical expressions exist in a given language and why they should be seen as "more than registers of physical experience" and also as "directed by cultural models of thought" (Sirvydé, 2006: 81). 


\subsection{Anger and extreme heat}

Non-literal expressions motivated by the "ANGER IS FIRE" metaphor appeared less frequently in the corpus in comparison to the CONTAINER metaphor, suggesting that the general metaphor "THE BODY IS A CONTAINER FOR THE EMOTIONS" was predominant in Croatian. However, data suggests that this version of the "ANGER IS HEAT" metaphor is very much productive in Croatian when it comes to the expressions containing the lexemes srdžba 'fury', gnjev 'wrath', and bijes 'rage' (only in the case of ljutnja 'anger' was the presence of the FIRE metaphor low in occurrence $6.67 \%)$ :

(7) a. Njegova ljutnja je buknula.

His anger [she] combust-PERF.

His anger combusted.

b. Upravitelj grada plamti od bijesa.

Manager city-GEN burn-IMPERF from rage.

The mayor is burning with rage.

c. Pa sav svoj bijes na ove kraje riga.

So all his rage [he] on this country breathe-IMPERF.

So he is breathing all his rage onto this country.

d. No srećom počeo je jenjati bijes.

But luckily [he] begin-PERF smolder-IMPERF rage.

But luckily the rage began dying away.

e. To ponovo u njemu razgori bijes.

This again in him catch-PERF rage.

This causes the rage to fan the fire in him again.

f. Najednom se u njemu ražari bijes.

Suddenly in him [he] rekindle-PERF rage.

Suddenly the rage rekindled in him.

g. kada je mislio da je gnjev djedov malo ohladio

when [he] think-PERF that wrath grandpa-GEN a little [he] coolPERF

when he began to think his grandpa's wrath cooled down

The FIRE metaphor seems to be most productive in Croatian when the expression corresponds to either Stage 4 (loss of control) or Stage 5 (act of retribution) in the anger scenario. Our emotion thus becomes like fire and assumes all of its physical properties. Anger in Croatian can burst into flames (buknuti) or catch fire (razgoriti) $(7 \mathrm{a}, \mathrm{e})$ as it can be spread onto our 
surroundings in an act of retribution (rigatibijes 'breathe rage'). Like fire, it can also lose intensity $(7 \mathrm{~d})$ or be entirely put out $(7 \mathrm{~g})$. The intensity of the emotion is thus tied to temperature - the hotter the fire in the body, the stronger the emotion. If we examine the data compiled for each of the four lexemes accordingly, we can see that gnjev 'wrath' yielded the highest percentage of metaphorical uses motivated by the FIRE metaphor $(26.50 \%)$. This could be explained by the etymology of the word itself, which is derived from the Old Slavic language, in which it was used to signify the act of burning and fire itself (Old slav. gněv 'heat') (Stanojević, 2013: 108). Moreover, the word is frequently used to indicate the power of a divine entity and is commonly found in such collocations in texts with a religious character:

(8) a. Jahve, planu li tvoj gnjev na rijeke

Yahweh, flare up-IMPERF if your wrath on rivers

Yahweh, if your wrath flares up onto the rivers

b. Gnjev Jahvin žestoko planu.

Wrath Yahweh-GEN violently flare up-PERF.

The wrath of Yahweh flared up violently.

c. Gnjev bi Jahve, Boga tvoga, usplamtio protiv tebe.

Wrath Yahweh-GEN, God you-GEN, burst-FUT against you.

The wrath of Yahweh, your God, will burst into flames against you.

d. ili će Božji gnjev planut' poput vatre, raspalit se neugasivo or God-GEN wrath flare up-FUT likefire, ignite-FUT unquenchably or the wrath of God will flare up like fire, ignite unquenchably

Gnjev Božji 'the wrath of God' is a term which is frequently used metaphorically in relation to the FIRE metaphor, which has been confirmed in our corpus analysis (8a-d). Since the majority of Croatian L1 speakers declare themselves as Christians, it is not unusual that such a frequent biblical theme as 'fire' would find its way into the language. Culture, or, to be more precise, religion, seems to have played a part in the manner in which the FIRE metaphor is represented in Croatian.

Corpus analysis yielded a significant number of metaphorical uses $(f=$ 71) motivated by the "ANGER IS AN OBJECT METAL THAT IS STEELED" metaphor, which is apparently very productive in the Croatian language. Anger is thus perceived as a metal object which is being shaped, presumably in fire:

(9) a. Vidjelo se, da je jedva čekao da iskali nakupljeni bijes. [It] see-PERF, that barely [he] wait-PERF to steel-IMPERF pentup rage.

You could tell he could barely wait to steel his pent-up rage. 
b. Tad odlučih iskaliti srdžbu na njima.

[I] then decide-PERF steel-IMPERF fury on them.

Then I decided to steel my fury on them.

c. sudjeluje u primitivnom iskaljivanju bijesa prema političkim neistomišljenicima

[he] participate-IMPERF in primitive steeling rage-GEN towards political opponents

he takes part in the primitive steeling of rage towards political opponents

d. Žurio se kući da na njoj iskali sav svoj bijes.

[He] hurry-PERF home so on her steel-IMPERF all his rage.

He hurried home so he could steel all his rage on her.

e. Liječnici su razočarani i sav svoj bijes iskaljuju na meni.

Physicians disappoint-PASS and all their rage [they] steelIMPERF on me.

The physicians are disappointed so they are steeling all their rage on me.

Evidence suggests that gnjev 'wrath' and bijes 'rage' lexemes usually appear in collocations indicative of the "ANGER IS AN OBJECT METAL THAT IS STEELED" metaphor. On the one hand, anger is an object steeled upon the entity or object that is the cause of the emotion in the first place. If we take into account that the act of steeling exerts great strength from the blacksmith, who attempts to change the shape of the object by exposing it to physical blows and high temperatures, it is not unusual that this specific source domain serves to contextualize great anger and loss of control, i.e. wrath or rage. On the other hand, it is also possible to steel anger in Croatian on objects or people who are not necessarily the cause of our emotion $(9 \mathrm{~d}$ -e). Unlike the FIRE metaphor, this metaphor involves not only fire, i.e. high temperatures, but also physical violence, which is demonstrated in the act of retribution in the attempt to rid oneself from negative emotions.

\subsection{Anger as a living being}

Anger in Croatian is also perceived as a living being, frequently as either a being that awakens or grows in size:

(10) a. Sve više je rasla srdžba u njemu.

All the more grow-PERF fury in him.

Fury kept growing inside him more and more. 
b. Probudi gnjev i srdžbu izlij.

[You] awaken-IMPERF wrath and fury pour-IMPERF.

Awaken your wrath and pour your fury.

c. U meni se stao buditi bijes.

In me [he] start-PERF awaken-IMPERF rage.

Rage started to awaken inside me.

d. Vjeruje da će se gnjev oko njegovog ulaska u vladu stišati.

[He] believe-IMPERF that wrath about his joining in cabinet quiet-IMPERF.

He believes the wrath regarding him joining the cabinet will quiet down.

e. Srdžba se opet polagano stiša.

Fury again slowly quiet-PERF.

Fury gradually quieted down again.

The two subversions of the "ANGER IS A LIVING BEING" metaphor, "ANGER IS A LIVING BEING THAT AWAKENS" and "ANGER IS A LIVING BEING THAT GROWS", yield a number of metaphorical expressions in Croatian which are used to describe the offending event or the inception of anger itself. The person begins to feel angry, but is yet to lose control over their emotions. If attempt at control is successful, the anger will subside and the act will be realized through another version of the LIVING BEING metaphor, "ANGER IS A LIVING BEING THAT MAKES NOISE" (10d-e). Anger in Croatian is also conceptualized as a dangerous being, frequently as a dangerous animal:

(11) a. Neka te zubima rastrgaju i zasite svoj bijes.

Let them teeth [they] tear-IMPERF you and feed-IMPERF their rage.

Let them tear you apart with their teeth and feed their rage.

b. Rekao je jedva susprežući bijes.

[He] say-PERF barely restrain-IMPERF rage.

He said it barely restraining his rage.

c. Od njihova se dodira propne u njoj divlji prezir i bijes.

From their touch rear up-PERF in her wild contempt and rage.

Their touch reared up wild contempt and rage in her.

d. Gnjev mu bolno stisnu srce kao pandžama.

Wrath painfully clutch-PERF his heart like with claws.

Wrath clutched his heart painfully as if with claws. 
e. Izjeda nas tvoja srdžba.

Devour-IMPERF us your fury.

Your fury is devouring us.

f. Samo je djelić mene osjetio ubod ljutnje.

Only small part me-GEN feel-PERF sting anger-GEN.

Only a small part of me felt the sting of anger.

Anger is perceived as an animal out of control, either due to hunger (zasititi 'feed', izjedati 'devour') or external agitation (11c). It is not always clear which animal anger is conceptualized as, however, a significant number of metaphorical occurrences related to the "ANGER IS AN ANIMAL OUT OF CONTROL" metaphor contains the action verb propeti 'rear up', which is used to describe the act of rising up on one's hind legs and raising one's fore legs into the air, a behavior indicative of a horse.

Many metaphorical uses registered in the corpus analysis conceptualized anger as a living being attacking the person experiencing the emotion. These occurrences were categorized as examples of the "ANGER IS AN $O P P O N E N T$ " metaphor and were analyzed separately due to their frequency of occurrence in the corpus:

(12) a. Žene lakše suzbijaju ljutnju nego muškarci.

Women easier hold-IMPERF anger than men.

Women hold anger back easier than men.

b. A kako se odrvati bijesu?

But how to wrestle-IMPERF rage?

But how to wrestle off rage?

c. Uspjeli smo svladati bijes.

[We] succeed-PERF conquer-IMPERF rage.

We managed to conquer rage.

d. Sav se bijes sručio na pripadnicu prometne mladeži.

All rage come-PERF on member traffic patrol youth-GEN.

All the rage came upon the member of the traffic patrol youth.

e. One koji trguju ustupcima sustiže birački bijes.

Those who trade-IMPERF in favors catch-IMPERF voters-GEN rage.

The voters' rage catches those who trade in favors.

f. Sad je Marka uhvatio gnjev.

Now Marko catch-PERF wrath.

Now wrath caught up with Marko. 
Anger in Croatian is conceptualized as an attacker who needs to be overpowered if the emotional state is to be resolved. Frequently enough the emotion does not go away, but is simply put under control (suzbiti' overpower, hold back'). This is to say, it can resurface if the offending event is repeated. The data also revealed a significant number of expressions in which anger is perceived as an opponent who is chasing the person experiencing the emotion (12e-f).

\subsection{Regarding culture}

A significant number of non-literal uses could not be categorized under either of the studied CMs and were consequently all grouped as unsorted expressions. Some of these metaphorical expressions are instantiations of other known CMs, but were not categorized separately due to their low frequency of occurrence in the corpus. Other CMs registered in the corpus include the following: "ANGER IS A STORM" (srdžba grmi 'fury thunders'), "ANGER IS ELECTRICITY" (naboji srdžbe 'fury's charges'), "ANGER IS SNOW" (gnjev se otapa s njega kao snijeg s bora "wrath is melting off of him like snow on a pine tree'), and "ANGER IS A FLOOD" (val bijesa 'wave of rage', poplava bijesa 'flood of rage'). However, what we found interesting and possibly evidence of cultural interference, was the issue of colors, namely, its diversity in Croatian when it is used to describe anger:

(13) a. Gubino je lice bilo crveno od bijesa.

Guba's face be-PERF red from rage.

Guba's face was red from rage.

b. Sin je, zelen od bijesa, nasrnuo na mater.

Son, green from rage, assault-PERF on mother.

The son, green from rage, assaulted his mother.

c. Građani su dotrčali do vijećnice, blijedi od gnjeva.

Townspeople run-PERF towards city hall, pale from wrath.

The townspeople ran towards the city hall, pale from wrath.

d. Građani požutješe od gnjeva.

Townspeople turn-PERF yellow from wrath.

The townspeople turned yellow from wrath.

e. u bijesu, modar od srdžbe

in rage, blue from fury

in rage, blue from his fury

The redness in the face and neck area (13a) is indicative of the CONTAINER metaphor, where the red color is the result of inner turmoil, 
raised bodily temperature and internal pressure. Red is the color of blood which, under emotional strain, rushes through our veins straight to our head (this is why we find equivalent expressions like Puknut će $t i$ žila 'You'll burst a blood vessel' in languages where the CONTAINER metaphor is found very productive, such as Croatian and English). Owing to the pervasiveness of the CONTAINER metaphor in Croatian, the color red was recorded most frequently in the non-literal expressions used to describe the emotional state of anger. However, examples were found which suggest other colors are used to describe anger in Croatian, such as green, white, yellow, and blue (13b-e). It is not inconceivable that culture was also a motivating factor behind these expressions, and perhaps the ancient humoral doctrine discussed by Dobrovol'skij and Piirainen (2005) did leave traces in many of the contemporary expressions found across different languages. According to this medieval doctrine, anger was seen as an overproduction of yellow bile whereas envy, an emotion closely related to anger, was perceived green or yellow. Since the Baltic region has always been under the influence of both Western and Middle Eastern cultures due to its geographical position, different cultural models and beliefs could have realized themselves in the languages spoken there and this could suggest the reason why different colors are used to describe one and the same emotion.

\section{CONCLUDING REMARKS}

This study is an attempt to provide an extensive analysis of the metaphorical conceptualizations of anger in the Croatian language. Several metaphors, whose existence has been confirmed in other world languages, were confirmed in the corpus search, thus reinforcing the suggested universal status of the central metaphor "ANGER IS HEAT" and its subversions, "ANGER IS A HOT FLUID IN A CONTAINER" and "ANGER IS FIRE". Several metaphors registered in the analysis have yet to gain a universal status, but have nevertheless been recorded in other languages apart from Croatian, such as the "ANGER IS HOT AIR IN A CONTAINER" metaphor, whose presence has been confirmed in both Japanese and Chinese. The study revealed language-specific metaphors such as "ANGER IS AN OBJECT METAL THAT IS STEELED" which, albeit present in several Slavic languages, is far more elaborate in Croatian, where it motivates a significant number of angerrelated metaphorical expressions. The analysis of the corpus database also yielded non-literal uses, which either defied categorization (12b-e) or could not be categorized under any of the high-frequency metaphors included in the data analysis.

Conceptual Metaphor Theory draws on the universality of human experiences, but with disregard to culture-specific variables which include, but are not limited to, religion, geographical position, mythology, and social 
norms. Nevertheless, conceptual metaphors present a viable starting point in the attempt to categorize the abundance of metaphorical expressions appearing across different languages. This study confirms the universality of certain conceptualizations of anger (the CONTAINER and FIRE metaphors), which have been registered in different languages, however, it also yields support to the belief that cultural factors play a role in the motivation of many metaphorical expressions and that etymological development should also be taken into account when attempting to decipher the motivational mechanisms behind many linguistic units.

\section{REFERENCES}

Boers, F. (2003) Applied linguistics perspectives on cross-cultural variation in conceptual metaphor. Metaphor and Symbol 18 (4), 231-238.

Chen, P. (2010) A Cognitive Study of "Anger" Metaphors in English and Chinese Idioms. Asian social science $6(8), 73-76$.

Dobrovol'skij, D. and Piirainen, E. (2005) Cognitive theory of metaphor and idiom analysis. Jezikoslovlje 6 (1), 7-35.

Fauconnier, G. and Turner, M. (2002) The Way We Think: Conceptual Blending and the Mind's Hidden Complexities. New York: Basic Books.

Fernando, C. and Flavell, R. H. (1981) On Idiom: Critical View and Perspectives (Vol. 5). Exeter: University of Exeter Press.

Gevaert, C. (2005) The ANGER IS HEAT question: Detecting cultural influence on the conceptualization of ANGER through diachronic corpus analysis. In Delbecque, N., van der Auwera, J. and Geeraerts, D. (eds) Perspectives on variation: sociolinguistic, historical, comparative. Berlin; New York: Mouton de Gruyter, 195-208.

Gibbs Jr, R. W. (1993) Literal meaning and figurative language. Discourse Processes 16 (4), $387-403$.

Gibbs Jr, R. W. (1996) Why many concepts are metaphorical. Cognition 61 (3), 309-319.

Gibbs Jr, R. W. (2003) Embodied experience and linguistic meaning. Brain and language 84 (1), 1-15.

Gibbs, Jr, R. W. and Colston, H. L. (2012) Interpreting figurative meaning. Cambridge: Cambridge University Press.

Giora, R. (2002) Literal vs. figurative language: Different or equal? Journal of pragmatics 34 (4), $487-$ 506.

Grady, J. E. (1997) Foundations of meaning: Primary metaphors and primary scenes. Berkeley: University of California.

Pragglejaz Group (2007) MIP: A method for identifying metaphorically used words in discourse. Metaphor and Symbol 22 (1), 1-39.

Kövecses, Z. (1995) Anger: Its language, conceptualization, and physiology in the light of cross-cultural evidence. In Taylor, J. R. and MacLaury, R. E. (eds) Language and the Cognitive Construal of the World. Berlin; New York: Mouton de Gruyter, 181-196.

Kövecses, Z. (2000) The concept of anger: Universal or culture specific? Psychopathology 33, 159-170.

Kövecses, Z. (2002) Cognitive-linguistic comments on metaphor identification. Language and Literature $11(1), 74-78$.

Kövecses, Z. (2003) Language, figurative thought, and cross-cultural comparison. Metaphor and Symbol 18 (4), 311-320.

Kövecses, Z. (2005) Metaphor in culture: Universality and variation. Cambridge University Press.

Kövecses, Z. (2011) Methodological issues in conceptual metaphor theory. In Handl, S. and Schmid, H.-J. (eds) Windows to the mind: Metaphor, metonymy and conceptual blending. Berlin; New York: De Gruyter Mouton, 23-40.

Lakoff, G. (2008) The neural theory of metaphor. In Gibbs, R. (ed) The Cambridge Handbook of Metaphor and Thought. New York: Cambridge Universtiy Press, 17-38. 
Lakoff, G. and Johnson, M. (1980) Metaphors we live by. Chicago: University of Chicago Press.

Lakoff, G. and Kövecses, Z. (1987, January) The cognitive model of anger inherent in American English. Cultural models in language and thought, 195-221.

Li, X. (2010) Conceptual metaphor theory and teaching of English and Chinese idioms. Journal of Language Teaching and Research 1 (3), 206-210.

Matsuki, K. (1995) Metaphors of anger in Japanese. In Taylor, J. R. and MacLaury, R. E. (eds) Language and the Cognitive Construal of the World. Berlin; New York: Mouton de Gruyter, 137-151.

Murphy, G. L. (1996) On metaphoric representation. Cognition 60 (2), 173-204.

Omazić, M. (2014) Konceptualna metafora u frazeologiji [Conceptual Metaphor in Phraseology]. In Stanojević, M. M. (ed) Metafore koje istražujemo. Zagreb: Srednja Europa d.o.o., 27-45.

Pronk, T. (2012) Where do our emotions come from? (On the etymology and semantic development of Croatian words relating to emotions). In Kapetanović, A. (ed) Poj željno! Iskazivanje i poimanje emocija u hrvatskoj pisanoj kulturi srednjega i ranoga novoga vijeka. Zagreb: Institut za hrvatski jezik i jezikoslovlje, 1-24.

Ruiz de Mendoza, F.J. and Peña, M.S. (2005) Conceptual interaction, cognitive operations, and projection spaces. In Ruiz de Mendoza, F. J. and Peña, M. S. (eds) Cognitive Linguistics: Internal Dynamics and Interdisciplinary Interaction. Berlin/New York: Mouton de Gruyter, 254-280.

Sirvydé, R. (2006) Facing Fear: A Corpus-based Approach to Fear Metaphors in English and Lithuanian. Zmogus ir žodis 3, 81-88.

Stanojević, M. M. (2013) Konceptualna metafora: temeljni pojmovi, teorijski pristupi i metode [Conceptual Metaphor: Basic terminology, theoretical approaches and methodology]. Zagreb: Srednja Europa d.o.o.

Wierzbicka, A. (1992) Defining emotion concepts. Cognitive Science 16 (4), 539-581.

Wray, A. (2000) Formulaic sequences in second language teaching: Principle and practice. Applied linguistics 21 (4), 463-489.

Yu, N. (2008) Metaphor from body and culture. In Gibbs, R. W. (ed) The Cambridge Handbook of Metaphor and Thought. New York: Cambridge University Press, 247-261. 


\section{ZAŠTO JE LJUTNJU MOGUĆE SIPATI, KALITI I KUHATI: KORPUSNO ISTRAŽIVANJE METAFORA LJUTNJE U HRVATSKOM JEZIKU}

Teorija konceptualne metafore (CMT) koju su predložili Lakoff i Johnson (1980) svojom je ekskluzijom kulturoloških faktora kao motivacijskih činitelja u pozadini metaforičkih izraza omogućila pojavu drugih teorija poput one konvencionalnog figurationog jezika (Dobrovol'skij i Piirainen, 2005). Glavni doprinos ovoga rada čini prikaz metafora ljutnje u odabranom korpusu hrvatskog jezika s obzirom na njihovu učestalost pojavljivanja u metaforičkim rečenicama odabranih kroz proceduru MIP (metaphor identification procedure). Metafora LJUTNJA JE TOPLINA te njezine dvije inačice, LJUTNJA JE VRUĆA TEKUĆINA U POSUDI i LJUTNJA JE VATRA, pokazale su se izrazito produktivnima u hrvatskome, time doprinoseći tvrdnji o univerzalnom statusu tih metafora. Analizom su dobiveni i primjeri metafore LJUTNJA JE VRUĆI ZRAK U POSUDI kao i primjeri upotrebe različitih boja u opisima ljutnje što upućuje na kulturološki razvoj kao utjecajni faktor.

Ključne riječi: ljutnja, konceptualna metafora, univerzalnost, korpusno istraživanje. 